\title{
Nursing Productivity of Tertiary General Hospitals using Financial Statements
}

\author{
Noh, Wonjung ${ }^{1 \oplus} \cdot$ Lim, Ji Young ${ }^{2 ®}$ \\ ${ }^{1}$ College of Nursing, Gachon University \\ ${ }^{2}$ Department of Nursing, Inha University
}

Purpose: This study was performed to analyze financial ratios and nursing productivity and to interpret comparisons of financial standard ratios. Methods: The financial statements of 21 tertiary general hospitals were collected from the webpage of the National Tax Service in Korea. General characteristics of the hospitals were acquired from their webpages. Results: The results obtained were compared with the financial standard ratios of Korean hospitals. The majority of hospitals showed poor liquidity, performance, turnover, and growth. Nursing productivity was measured by calculating annual value added per nurse ( $W 39,746,938$ ) and annual gross revenues per nurses $(W 65,803,550)$. Conclusion: Interestingly, although the financial ratios were generally poor, nursing productivities were very good. Nurse managers can suggest increasing nursing staff levels based on high nursing productivity despite poor financial conditions.

Key Words: Nursing productivity; Financial statements; Hospital

\section{INTRODUCTION}

Competition in the healthcare industry has become increasingly fierce, and hospitals demand rapid growth to adapt to these changes [1,2]. As hospitals survive and attempt to thrive in the face of competition, they are greatly interested in developing effective growth strategies. Hospitals must develop business plans containing such elements as the hospital's mission, strategic plans, structure, and financial statements to grow [3]. Financial statements demonstrate financial performance through balance sheets and income and cash flow statements [4]. The financial ratio is analyzed from four perspectives to evaluate hospitals' financial statuses: liquidity, profitability, activity, and growth [5]; hospital management utilizes this information to make decisions regarding equipment and workforce investments. Financial ratios are a useful way to compare the financial situation of different companies with different characteristics by analysing the relationship between two or more items presented in the financial statements [6].

As many hospitals experience considerable pressure to increase financial performance, nursing unit managers must also meet hospitals' demands. Nurse managers must demonstrate their staff's nursing performance to hospital CEOs (chief executive officers) by analyzing financial information to attract investments in nursing units. As South Korea's health policies continue to move toward an industrial model, nurse managers are also required to present management activities based on financial statements. They must prove nursing performance by proving financial performance in terms of nursing productivity.

A previous study defined nursing productivity as a ratio of output to input [7]. As nursing productivity affects the quality of patient care and nurse staffing, the management of nursing productivity is important for nurse managers $[8,9]$. Seven nursing grades are calculated in Korea with a nurse staffing to inpatient ratio. The first nursing grade in tertiary general hospitals signifies that one nurse cares for two inpatients. The higher the nursing grade, the more incentives are paid to hospitals from the National Health Insurance Service in Korea [10]. As nursing units' income depends on nursing grades, the influence of nurs-

Corresponding author: Lim, Ji Young

Department of Nursing, Inha University, 100 Inha-ro, Michuhol-gu, Incheon 22212, Korea.

Tel: +82-32-860-8210, Fax: +82-32-874-5880, E-mail: lim20712@inha.ac.kr

Received: Oct 15, 2018 | Revised: Dec 15, 2018 | Accepted: Dec 27, 2018

This is an open access article distributed under the terms of the Creative Commons Attribution Non-Commercial License (http://creativecommons.org/licenses/ by-nc/3.0), which permits unrestricted non-commercial use, distribution, and reproduction in any medium, provided the original work is properly cited. 
ing productivity is vital to nurse managers who wish to prove their units' performance.

It is also important that accurate and reliable information is used when nurse managers calculate nursing productivity [11]. Nurse managers use financial statements to obtain reliable information, such as revenue and cost data. Further, hospital CEOs perceive descriptions of nursing productivity based on financial statements as more reliable. Although the usefulness of nursing productivity based on financial statements has come to the fore, few studies have proven nursing productivity using financial information. Accordingly, we considered that a study was necessary to understand tertiary general hospitals' financial statuses and to verify nursing productivity.

\section{Aim}

The present study's aim is threefold, as follows: First, to provide an analysis of tertiary general hospital financial statuses using financial ratios; second, to evaluate nursing units' performances using a nursing productivity analysis; and third, to interpret tertiary general hospitals' financial statuses and nursing productivities by comparing financial standard ratios.

\section{METHODS}

\section{Study Design}

The study was conducted using a descriptive, cross-sectional design.

\section{Sample}

For this study the financial statements of 21 general hospitals in Korea were sampled. The sampling was for financial statements. that had no blank values and included 44 general hospitals in Korea publicly announced in 2012.

\section{Instruments}

\section{1) Financial ratio analysis}

For this study analysis was done of the financial ratio as described by the hospital accounting system issued by the Korean Health Industry Development Institute (KHIDI) (2005). This accounting system provides formulae to perform financial ratio analysis using four categories: liquidity, performance, turnover, and growth. Liquidity is a category to determine the soundness of hospital capital structure and the adequacy of the fund operation, utilizing the indicators such as current ratio, liability to total assets, and net asset to total assets [12-14]. In this study, liability to total assets and current ratio indicators were considered to analyze liquidity. Performance category is assessed by indicators such as return to assets, net profit to total assests, and net profit to gross revenues [12-14]. In this study, we analyzed the data using net profit to total assets and net profit to gross revenue indicators. Turnover is usually identified by indicators total assets turnover, patient receivables turnover, and average collection period to assess how efficiently an asset is operated to earn revenue [1214]. It was evaluated using the turnover of both total assets and patient receivables. Growth category is determined by how much the current period has increased and decreased compared to the prior term [12]. As it is generally assessed by growth rate of patient revenues and growth rate of total assets $[13,14]$, those two indicators were also used in this study. Table 1 provides the formulae used to calculate these indicators.

\section{2) Nursing productivity}

Nursing productivity is defined as the ratio of output to input in nurse practice [7], and was calculated in this study using the indicators for the annual value added and annual gross revenues per nurse, as determined using the hospital accounting system [15].

\section{3) Financial standard ratios}

A proper comparison between hospitals' nursing productivity does not only use financial ratios, as hospitals' characteristics differ, including their ownership, number of beds, and establishment years. Financial standard ratios have been used to evaluate and compare nursing productivities [16], because financial standard ratios are representative average scores of financial ratios, they are typically used as comparative criteria when a hospital's financial status is evaluated. This study used the 2012 Hospital Management Statistics' suggested financial standard ratios [17], which are provided in Table 1.

\section{Measurement and Data Analysis}

Tertiary general hospitals' financial statements were collected from Korea's National Tax Services website, and the hospitals' general characteristics were derived from the information disclosed on their websites. The financial statements were analyzed regarding four financial ratio analysis categories: liquidity, performance, turnover, and growth. Nursing productivity was also analyzed using financial statements, and the results of the four categories 
Table 1. Formulas of Indicators and Financial Standard Ratios

\begin{tabular}{|c|c|c|c|c|}
\hline \multirow[b]{2}{*}{ Financial ratio } & \multirow[b]{2}{*}{ Indicator } & \multirow[b]{2}{*}{ Formulas } & \multicolumn{2}{|c|}{ Financial standard ratios } \\
\hline & & & $\begin{array}{l}500 \sim 1,000 \\
\text { Beds }\end{array}$ & $\begin{array}{c}1,000+ \\
\text { Beds }\end{array}$ \\
\hline \multirow[t]{2}{*}{ Liquidity } & $\begin{array}{l}\text { Liability to total } \\
\text { assets (\%) }\end{array}$ & $\begin{array}{l}\text { Liability/ } \\
\text { total assets } * 100\end{array}$ & 73.1 & 62.1 \\
\hline & Current ratio (\%) & $\begin{array}{l}\text { Current assets/ } \\
\text { current liability }{ }^{*} 100\end{array}$ & 86.8 & 122.7 \\
\hline \multirow[t]{2}{*}{ Performance } & $\begin{array}{l}\text { Net profit to total } \\
\text { assets }(\%)\end{array}$ & $\begin{array}{l}\text { Current net profit/ } \\
\text { total assets*100 }\end{array}$ & -0.2 & 0.5 \\
\hline & $\begin{array}{l}\text { Net profit to gross } \\
\text { revenues }(\%)\end{array}$ & $\begin{array}{l}\text { Current net profit/ } \\
\text { gross revenues*100 }\end{array}$ & -0.2 & 0.4 \\
\hline \multirow[t]{2}{*}{ Turnover } & $\begin{array}{l}\text { Total assets turnover } \\
\text { (cycles) }\end{array}$ & $\begin{array}{l}\text { Gross revenues/ } \\
\text { total assets }\end{array}$ & 1.46 & 1.1 \\
\hline & $\begin{array}{l}\text { Patient receivables } \\
\text { turnover (cycles) }\end{array}$ & $\begin{array}{l}\text { Gross revenues/ } \\
\text { Average patient receivables }\end{array}$ & 9.94 & 10.3 \\
\hline \multirow[t]{2}{*}{ Growth } & $\begin{array}{l}\text { Growth rate of gross } \\
\text { revenues }(\%)\end{array}$ & $\begin{array}{l}\text { (Current gross revenues-previous gross revenues)/ } \\
\text { previous gross revenues * } 100\end{array}$ & 4.7 & 4.6 \\
\hline & $\begin{array}{l}\text { Growth rate of total } \\
\text { assets }(\%)\end{array}$ & $\begin{array}{l}\text { (Current total assets-previous total assets)/ } \\
\text { previous total assets }{ }^{*} 100\end{array}$ & 6.5 & 3.3 \\
\hline \multirow[t]{2}{*}{$\begin{array}{l}\text { Nursing } \\
\text { productivity }\end{array}$} & $\begin{array}{l}\text { Annual value added } \\
\text { per nurse (W) }\end{array}$ & $\begin{array}{l}\text { Value added / } \\
\text { number of nurses }\end{array}$ & $10,123,700$ & $10,351,600$ \\
\hline & $\begin{array}{l}\text { Annual gross revenues } \\
\text { per nurse (W) }\end{array}$ & $\begin{array}{l}\text { Gross revenues / } \\
\text { number of nurses }\end{array}$ & $21,946,300$ & $25,133,100$ \\
\hline
\end{tabular}

and nursing productivity were compared with the financial standard ratios of hospitals in Korea. Generally, the financial ratio is compared to the financial standard ratio in two groups only, but this study classified it into four groups for detailed analysis. The detailed classification criteria were based on the financial standard ratio to increase or decrease by more than $100 \%$. The financial ratio results were classified as "Very Good," "Good," "Poor," or "Very Poor." "Very Good" indicated a financial ratio at least twice as high as the financial standard ratio, and "Good" indicated a ratio above the financial standard ratio. "Poor" indicated a lower ratio that the financial standard ratio, and "Very Poor" indicated a low ration over half the financial standard ratio.

\section{RESULTS}

\section{General Characteristics}

Of the 21 hospitals, $90.5 \%$ were privately owned, and $52.4 \%$ were located in a province; $57.1 \%$ were established 20 to 40 years ago. Most had 500 to 1,000 beds and were of a third nursing grade, employing an average of 304.46 nurses. The hospitals' total average assets were 3.9 billions Won and their average total liabilities were 10.3 billions Won. Table 2 provides detailed information on the 21 hospitals.

\section{Financial Ratios and Nursing Productivity}

The 21 hospitals' financial ratios were then analyzed using the four categories of liquidity, profitability, activity, and growth.

First, the liability and current ratios were calculated to assess liquidity; the hospital liability to total assets was $29.9 \%$ and the current ratio was $97.7 \%$. A majority of the hospitals exhibited poor liquidity. Second, hospital profitability was assessed by the net profit to total assets and net profit to gross revenue. Half of the hospitals demonstrated good profitability, but the others demonstrated poor profitability. The total assets turnover in the activity category was 0.26 cycles and the patient receivables turnover was 84.06 cycles. Almost all hospitals indicated poor activity. Finally, the growth category was analyzed using the growth rates of gross revenues and total assets to reveal that over two-thirds of the hospitals exhibited poor 
Table 2. General Characteristics

\begin{tabular}{|c|c|c|c|}
\hline Characteristics & Categories & $\mathrm{n}(\%)$ & $\mathrm{M} \pm \mathrm{SD}$ \\
\hline Owner & $\begin{array}{l}\text { Private } \\
\text { Public }\end{array}$ & $\begin{array}{c}19(90.5) \\
2(9.5)\end{array}$ & \\
\hline Location & $\begin{array}{l}\text { Urban } \\
\text { Province }\end{array}$ & $\begin{array}{l}10(47.6) \\
11(52.4)\end{array}$ & \\
\hline Establishment years & $\begin{array}{l}\text { Older than } 60 \text { years } \\
40 \sim 60 \text { years } \\
20 \sim 40 \text { years } \\
0 \sim 20 \text { years }\end{array}$ & $\begin{array}{r}2(9.5) \\
3(14.3) \\
12(57.1) \\
4(19.0)\end{array}$ & \\
\hline Number of beds & $\begin{array}{l}\text { More than } 1,000 \text { beds } \\
500 \sim 1,000 \text { beds }\end{array}$ & $\begin{array}{c}2(9.5) \\
19(90.5)\end{array}$ & \\
\hline Nursing grade* & $\begin{array}{l}1 \text { st } \\
2 \text { nd } \\
3 \text { rd }\end{array}$ & $\begin{array}{c}1(4.8) \\
4(19.0) \\
16(76.2)\end{array}$ & \\
\hline Number of nurses (people) & & & $304.46 \pm 140.18$ \\
\hline Total assets (W) & & & $38,929,341,743 \pm 48,199,643,160$ \\
\hline Total liabilities (W) & & & $103,555,268,962 \pm 52,561,442,288$ \\
\hline Gross revenues (W) & & & $215,159,477,716 \pm 113,967,063,138$ \\
\hline Net income (W) & & & $-254,660,250 \pm 4,873,892,133$ \\
\hline
\end{tabular}

*Nursing grade is classified by seven grades (ranging from one to seven) according to the number of nurses per bed for inpatients, which affects inpatient nursing costs (Health Insurance Review \& Assessment Service, 2014).

Table 3. Financial Ratios and Nursing Productivity

$(N=21)$

\begin{tabular}{|c|c|c|c|c|}
\hline Financial ratio & Indicator & $\mathrm{M} \pm \mathrm{SD}$ & Minimum & Maximum \\
\hline \multirow[t]{2}{*}{ Liquidity } & Liability to total assets (\%) & $29.9 \pm 776.8$ & $-2,226.3$ & $1,111.9$ \\
\hline & Current ratio $(\%)$ & $97.7 \pm 70.3$ & 23.2 & 302.5 \\
\hline \multirow[t]{2}{*}{ Performance } & Net profit to total assets (\%) & $-3.6 \pm 19.7$ & -56.6 & 38.3 \\
\hline & Net profit to gross revenues (\%) & $-7.8 \pm 33.0$ & -151.5 & 4.1 \\
\hline \multirow[t]{2}{*}{ Turnover } & Total assets turnover (cycles) & $0.26 \pm 1.10$ & -3.5 & 2.5 \\
\hline & Patient receivables turnover (cycles) & $84.06 \pm 235.88$ & 1.0 & 927.4 \\
\hline \multirow[t]{2}{*}{ Growth } & Growth rate of gross revenues (\%) & $2.3 \pm 6.6$ & -25.4 & 7.4 \\
\hline & Growth rate of total assets (\%) & $9.9 \pm 38.0$ & -33.0 & 148.8 \\
\hline \multirow{2}{*}{$\begin{array}{l}\text { Nursing } \\
\text { productivity }\end{array}$} & Annual value added per nurse (W) & $39,746,938 \pm 25,094,285$ & $-489,199.4$ & $137,830,669.8$ \\
\hline & Annual gross revenues per nurse (W) & $65,803,550 \pm 41,291,027$ & $539,656.2$ & $227,218,841.8$ \\
\hline
\end{tabular}

growth. Tables 3 and 4 respectively illustrate the hospitals financial ratios and levels.

Nursing productivity was calculated using the annual value added and gross revenues per nurse. The annual value added per nurse was 39 millions Won, and the annual gross revenue per nurse was 65 millions Won; almost all hospitals indicated good nursing productivity. Tables 3 and 4 contain detailed information regarding nursing productivity.

\section{DISCUSSION}

Nursing productivity is important relative to evaluating the performances of hospitals' nursing departments. As nursing is a hospital's largest asset in hospitals regarding the number of staff and work volume, augmenting and managing nursing departments' performances is key to successful hospital management.

Our overall results indicate that the 21 tertiary general hospitals were not in good financial condition, but had 
Table 4. Financial Ratio Levels and Nursing Productivity

$(N=21)$

\begin{tabular}{|c|c|c|c|c|}
\hline Category & Indicator & Level & $\mathrm{n}(\%)$ & Range \\
\hline \multirow[t]{8}{*}{ Liquidity } & \multirow[t]{4}{*}{ Liability to total assets (\%) } & Very good & $5(23.8)$ & $-2,226.3 \sim 30.1$ \\
\hline & & Good & $1(4.8)$ & 69.0 \\
\hline & & Poor & $4(19.0)$ & $86.8 \sim 114.9$ \\
\hline & & Very poor & $11(52.4)$ & $206.8 \sim 1,111.9$ \\
\hline & \multirow[t]{4}{*}{ Current ratio $(\%)$} & Very good & $3(14.3)$ & 183.6 302.5 \\
\hline & & Good & $5(23.8)$ & $90.3 \sim 131.4$ \\
\hline & & Poor & $9(42.9)$ & $55.5 \sim 76.7$ \\
\hline & & Very poor & $4(19.0)$ & $23.2 \sim 43.1$ \\
\hline \multirow[t]{8}{*}{ Performance } & \multirow[t]{4}{*}{ Net profit to total assets (\%) } & Very good & $10(47.6)$ & $-0.1 \sim 38.3$ \\
\hline & & Good & $0(0.0)$ & - \\
\hline & & Poor & $0(0.0)$ & - \\
\hline & & Very poor & $11(52.4)$ & $-56.6 \sim-0.5$ \\
\hline & \multirow[t]{4}{*}{ Net profit to gross revenues (\%) } & Very good & $9(42.9)$ & $0.0 \sim 4.1$ \\
\hline & & Good & $1(4.8)$ & -0.1 \\
\hline & & Poor & $1(4.8)$ & -0.3 \\
\hline & & Very poor & $10(47.6)$ & $-151.5 \sim-0.5$ \\
\hline \multirow[t]{8}{*}{ Turnover } & \multirow{4}{*}{ Total assets turnover (cycles) } & Very good & $0(0.0)$ & - \\
\hline & & Good & $2(9.5)$ & $1.5 \sim 2.5$ \\
\hline & & Poor & $1(4.8)$ & 1.4 \\
\hline & & Very poor & $18(85.7)$ & $-3.5 \sim 0.7$ \\
\hline & \multirow[t]{4}{*}{ Patient receivables turnover (cycles) } & Very good & $4(19.0)$ & 47.1 927.4 \\
\hline & & Good & $0(0.0)$ & - \\
\hline & & Poor & $0(0.0)$ & - \\
\hline & & Very poor & $17(81.0)$ & $1.0 \sim 3.1$ \\
\hline \multirow[t]{8}{*}{ Growth } & \multirow[t]{4}{*}{ Growth rate of gross revenues (\%) } & Very good & $0(0.0)$ & - \\
\hline & & Good & $7(33.3)$ & $4.9 \sim 7.4$ \\
\hline & & Poor & $7(33.3)$ & $2.5 \sim 4.2$ \\
\hline & & Very poor & $7(33.3)$ & $-25.4 \sim 2.0$ \\
\hline & \multirow[t]{4}{*}{ Growth rate of total assets (\%) } & Very good & $5(23.8)$ & $21.7 \sim 148.8$ \\
\hline & & Good & $1(4.8)$ & 8.1 \\
\hline & & Poor & $1(4.8)$ & 5.4 \\
\hline & & Very poor & $14(66.7)$ & $-33.0 \sim 2.1$ \\
\hline \multirow{8}{*}{$\begin{array}{l}\text { Nursing } \\
\text { productivity }\end{array}$} & \multirow[t]{4}{*}{ Annual value added per nurse (W) } & Very good & $19(90.5)$ & $29,185,990.4 \sim 137,830,669.8$ \\
\hline & & Good & $0(0.0)$ & - \\
\hline & & Poor & $1(4.8)$ & $137,830,669.8$ \\
\hline & & Very poor & $1(4.8)$ & $-489,199.4$ \\
\hline & \multirow[t]{4}{*}{ Annual gross revenues per nurse (W) } & Very good & $19(90.5)$ & $48,121,170.5 \sim 227,218,841.8$ \\
\hline & & Good & $0(0.0)$ & - \\
\hline & & Poor & $1(4.8)$ & $14,920,867.2$ \\
\hline & & Very poor & $1(4.8)$ & $539,656.2$ \\
\hline
\end{tabular}

good nursing productivity, which indicates that nurses contributed to the hospitals' revenue despite the poor financial conditions of the whole hospital. As hospitals improve their financial statuses, we found they should determine the reasons for their poor financial conditions and provide strategic solutions. Hospital executives should identify causes of high nursing productivity in spite of overall poor hospital financial performance, provide incen- tives for nursing contributions, and benchmark the management strategies of nursing departments in other departments. Nurse managers must also suggest strategies to improve financial statuses and nursing productivity.

The results of this study suggests that nurse managers should focus on the result that almost all tertiary general hospitals had a third nursing grade. Nurses who work in third nursing grade hospitals care for more patients dur- 
ing their duties than those who worked in first nursing grade hospitals [10]. However, although most hospitals were of the third nursing grade, almost all had "Very Good" nursing productivity, despite their hospitals' poor financial conditions, which six financial indicators were "very poor" among eight financial indicators in four financial ration categories.

The result of analyzing the efficiency of nursing unit in a general hospital showed that the average efficiency of 18 nursing units in total was very high at 0.99 [18]. Previous study reported $82.01 \%$ of efficiency as a result of the efficiency analysis of 24 outpatient nursing units in one general hospital [19]. These previous studies support the results of this study which showed high nursing productivity. Therefore, it suggested that the higher the nursing grade, the more positive the nursing performance and contribution to the improvement of medical service quality [18]. This implies that the operation of the nursing unit is very efficient even if the situation of the ward changes according to the characteristics of the medical department. Therefore, it should be noted that it is an undesirable management practice to recognize nursing as a consumption department because only a large number of nurses is noted without a systematic analysis of nursing performance.

High nursing productivity means that increasing nurse numbers can improve their financial status. According to a previous study, as nurses are a crucial resource to the hospital, increasing the rate of nursing staffing contributes positively to the overall performance of the hospital affecting the economic performance of the medical institution as well as its clinical performance [20]. The results from the present study corresponds with earlier studies' results, which report that sufficient nursing staff reduces costs by increasing the quality of care and decreasing nurse turnover rates $[21,22]$. Thus, nurse managers can posit that nursing staff recruitment will improve nursing grades and increase productivity. Further, this provides data for nurse managers to explain the need to reinforce nursing staff.

As nurse managers use financial information to address nursing productivity, it will become apparent that increasing nurse managers' financial competency will allow them to further analyze financial statements and suggest strategies to improve nursing productivity and hospital financial status [20]. Therefore, nurse managers can also request a sufficient budget to improve nursing productivity when they create an incentive system for their nurses. From the hospital's perspective, an incentive system should be prepared based on nursing productivity, and it has been reported that nurse incentive systems positively effects job satisfaction and retention [23].

The financial statements used in this study constitute a cross-section of historical financial status, and a longitudinal analysis would extend this understanding. As this study was analyzed with data from some of the tertiary general hospital data, a careful approach is needed when applying the results to all hospitals. In addition, the indicators of nursing productivity was selected as presented by the Ministry of Health and Welfare and the Korea Health Industry Development Institute, but this is an indicator from a hospital management perspective, and there is a limitation that does not consider all aspects of nursing productivity.

\section{CONCLUSION}

This study was performed to understand tertiary general hospitals' financial status and to verify nursing productivity on hospital management perspectives. Overall, 21 tertiary general hospitals were in poor financial status, while their nursing productivity was excellent. Based on these financial statement analysis results, nursing managers will be able to present the nursing management strategies, such as nurse recruitment for improving productivity to the chief executive officer of the hospital. The results of this study can provide nursing management field with a foundation for evidence-based management regarding the merits of the nursing productivity data provided by financial statements.

\section{REFERENCES}

1. Gaynor M, Town R. The impact of hospital consolidation update. The Synthesis Project. Research Synthesis Report. 2012; 5:1-7.

2. Tsai TC, Jha AK. Hospital consolidation, competition, and quality: Is bigger necessarily better?. JAMA. 2014;312(1):29-30. https://doi.org/10.1001/jama.2014.4692

3. Brown, MDP. Understand your financial statement. Medical Economics. 2011;88(7):52-53.

4. Wagner K. 5 ways to teach physicians about financial management. Healthcare Financial Management. Journal of the Healthcare Financial Management Association. 2012;66(9):42-43.

5. Chiang JC, Wang TY, Hsu FJ. Evaluation of hospital financial performance in Taiwan following implementation of national health insurance. Does Highly Concentrated Market Inevitably Lead to Predatory Pricing?. The Case of the Mexican Banking Industry. 2014;7(2):43-52.

https://doi.org/10.5539/ibr.v7n2p43

6. Lim JY, Noh W. Financial Management for Nurses. HN Sci- 
ence: Seoul; 2014.

7. Holcomb BR, Hoffart N, Fox MH. Defining and measuring nursing productivity: A concept analysis and pilot study. Journal of Advanced Nursing. 2002;38(4):378-386.

https://doi.org/10.1046/j.1365-2648.2002.02200.x

8. Fagerstrm L, Lønning K, Andersen MH. The RAFAELA system: A workforce planning tool for nurse staffing and human resource management. Nursing Management. 2014;21(2):30-36. https://doi.org/10.7748/nm2014.04.21.2.30.e1199

9. Hall LM. Nursing intellectual capital: A theoretical approach for analyzing nursing productivity. Nursing Economic\$. 2003; 21(1):14-19.

10. Health Insurance Review \& Assessment Service. Nursing grade [Internet]. 2017. [cited October 12, 2018]. Available from: https://www.hira.or.kr/dummy.do?pgmid=HIRAA0200330 00000\#none.

11. Ellerbe $S$. What is driving the growing demand for consulting in hospital staffing, scheduling, and productivity?. Nursing Economic\$. 2013;31(5):237-240.

12. Korea Society of Health Service Management. Essentials of Hospital Management. Hyunmoonsa: Seoul; 2013

13. Lim JY, Noh W, Oh SE, Kim OG. Financial ratio analysis for developing nursing management strategies in university hospitals. Journal of Korean Academy of Nursing Administration. 2013;19 (1):7-16. https://doi.org/10.11111/jkana.2013.19.1.7

14. Korea Health Industry Development Institute. 2016 Statistics for Hospital Management. Korea Health Industry Development Institute: Cheongju; 2017.
15. Korea Health Industry Development Institute. 2004 statistics for hospital management, Korea Health Industry Development Institute: Seoul; 2005.

16. Yang DH, Kam HK. New hospital financial management. Bomungak: Seoul; 2011.

17. Korean Hospital Association, Korean Institute of Hospital Management. 2012 hospital management statistics. Korean Institute of Hospital Management: Seoul; 2013.

18. Lee SY, Lim JY. Evaluation of the efficiency of general nursing units using data envelopment analysis(DEA). Journal of Korean Academic Society of Home Health Care Nursing. 2011;18 (2):118-125.

19. Im HB, Lim JY. Evaluation of efficiency of outpatient clinic in a general hospital using data envelopment analysis (DEA). Journal of Korean Academic Society of Home Health Care Nursing. 2011;19(1):11-18.

20. Everhart D, Neff D, Al-Amin M, Nogle J, Weech-Maldonado $R$. The effects of nurse staffing on hospital financial performance: Competitive versus less competitive markets. Health Care Management Review. 2013;38(2):146-155. https://doi.org/10.1097/HMR.0b013e318257292b

21. O'Brien-Pallas L. Evidence-based standards for measuring nurse staffing and performance. Otawa, Ontario: Canadian Health Services Research Foundation; 2004.

22. Unruh L. Nurse staffing and patient, nurse, and financial outcomes. The American Journal of Nursing. 2008;108(1):62-71.

23. Wieck KL, Dols J, Northam S. What nurses want: The nurse incentives project. Nursing Economic\$. 2009;27(3):169-177, 201. 